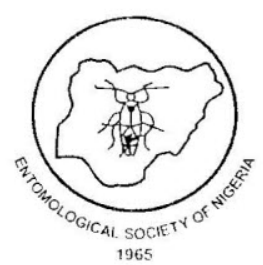

Nigerian Journal of Entomology

DOI:10.36108/NJE/7102/33(0120)

\title{
Conserving Insect Diversity in the Tropics: Challenges and Prospects
}

\author{
*KEHINDE, T.O. \\ Department of Zoology, Obafemi Awolowo University, \\ Ile-Ife, Nigeria
}

Nig.J. Entomol.33:7-15(2017)

\begin{abstract}
The tropical region is rich in biodiversity for many organisms including insects. It is also home to many endemic insect species and those which play crucial irreplaceable ecological roles. Tropical ecosystems are, however, under increasing threats from various anthropogenic pressures including, but not limited to deforestation, intensive agriculture and climate change. While attention has been drawn to biodiversity conservation in the tropics, little information is available on the challenges and prospects of conserving target groups such as insects. It is important to fill this knowledge gap since limited resources are available for conservation. Consequently, conservation priorities are often defined based on available information and data on different focal taxa. This review identifies the challenges to insect conservation in the tropics and emphasizes the need to fill critical knowledge and data gaps to ensure that insects in the tropics gain the important attention they deserve on a global conservation scale of preference. The critical threats and challenges identified in the tropics are climate change, alien invasion, habitat loss, sampling difficulties and the challenge of taxonomy. Various approaches to conservation were also considered. These include conservation priorities ranging from habitat-focused to organism-focused approaches. This will ensure that conservation efforts match up to the alarming rate of loss of insect diversity currently taking place in the tropics.
\end{abstract}

Keywords: Anthropogenic threats, Ecosystem services, Endemic, Extinction, Pollinator, Predators, Parasitoids

\section{INTRODUCTION}

Conserving biodiversity involves various stakeholders. including biologists, policy makers, governments, funding agencies and communities (DEFRA. 2002). Remarkable suceess would be possible when knowledge and efforts by these various groups are synergized simultaneously. However, limited success has been documented with increased calls to address emerging challenges beyond the year 2010 deadline set by the Consention on Biological Diversity (Rands et al., 2010). As risk of extinction and

\footnotetext{
"Corresponding author:

E-mail: topekchindeci gmail.com
}

biodiversity loss escalates, there is concomitant decline in ecosystem services offered by functionally important organisms such as insects (Rands etal., 2010).

The high diversity and crucial ecological role of insects have been reported in various habitat types and different climatic regions globally (Samways, 2005). The tropical region extends across the globe from Austral and Neotropical America in the West, to the Afrotropical region of sub-Saharan Africa and to the tropical countries of Asia in the East (Godtray et al., 1999). This region is the most diverse in the world containing an estimated $70 \%$ of the world's biodiversity (Dirzo and Raven, 2003; Greenfacts, 2012; Laurance, 1999), as well as a sizeable portion of the designated 
hotspots of biodiversity due to various threats associated with the floral and faunal diversity of this region (Myeretal., 200(): Pimmertal., 2014). This explains why high conservation value has been conferred on the biodiversity of this region, especially for insects, which are exceptionally diverse both in terms of taxonomic and functional diversity (Samways, 1994: 2005). Furthermore, rate of degradation and destruction of tropical forest habitats predicted to be home to an estimated 1 million insect species is higher than other climatic regions (Lew is and Basset, 2007: Pimm, 2001: Sala et al., 2000). This indicates that the tropics is prone to an escalation in the rate and extent of insect diversity loss as the planet faces a global biodiversity crisis. This review focuses on the needs, challenges and opportunities for conserving insects from a tropical perspective.

\section{Insect Diversity and Conservation: Global vis-a-vis Regional Trends}

The success of insects in terms of diversity, abundance and global distribution has been attributed to a wide range of factors (Samways, 1994). Their reproductive capabilities, flight, small size, extent of habitat colonization are key factors that have been identified as crucial to their survival and remarkable taxonomic and functional diversity (Tylianakis et al., 2010). Attempts at estimating the extent of diversity (number of species) as pioneered by Erwin (1982) and later by other biologists have shown estimates of between 5 andl() million species from the most recent estimates (Godfray et al.. 1999: Mora et al., 2011). Insect diversity in the tropics have been shown to parallel the hyper diverse plant community of this region (Novotny e't al., 2006). This is especially so for herbivorous and flower-risiting insects which interact closely with plants to fulfil important functional roles as pests and pollinators (Tscharntke el al., 2005). In contrast to records in the temperate region. it has been suggested that the tropies provide some additional resources that may be vital to insect life. This is further strengthened by the fact that supply and arailability of resources are airly eonstant in the tropics unlike fluctuations experienced in the temperate region due to extreme weather patterns (Samnegard et chl., 2015).

There is universal concern for biodiversity loss (Shah. 2011). This is of great interest among insect ecologists in the face of growing taxonomic bias against insects and other invertebrates in addressing the conservation challenge (Clark and May, 20(2) 2). Drivers of biodiversity loss act at local, regional and global scales (Greenfacts, 2012), hence the need for a holistic approach in conservation research and practice especially for highly mobile groups such as insects which have successfully colonized various habitat types and are capable of moving across local, regional and in some cases across national boundaries. Although insect loss is a global challenge. inventories, assessments and development of conservation strategies may be better targeted at local or regional scales. This would possibly remove the ambiguity that may result when conservation efforts are approached globally with limited consideration for local scale dynamics that shape insect diversity loss and conservation needs (Kehinde etal., 2014; Tscharntkeetal.,2008).

Also of paramount consideration is the need to understand the ecrogy of various insect species which may either ubiquitous or endemic to a particular region. This includes their functional roles, important ecological interactions, spatial and other temporal habitat requirements, This knowledge needs to be put in a dynamic and progressive perspective as the world faces challenges such as climate change on a global scak as well as regional threats such as deforestation in the tropics (Musolin. 2007). Apart from the negative impact of anthropogenic and natural disturbances in tropical habitats, there are limitations in compiling suitable ecological data that are crucial to conservation planning for insects (Godfray e't al., 1999). This includes sampling difliculties due to the nature of tropical ferests as well as low abundance of many insects species reported in the tropies (Balsset. 1999: Kehinde et (al., 201 1 : 1 .ew is and Basset. 2007). 


\section{Threats and Challenges Climatechange}

Climate waming has theatened both terrestrial and aquatic organisms orer the past few decades. Various challenges ranging from shifts in the distribution range and abundance of organisms as well as extinction threats have been reported Thomas it al.. 20(04). Other conlogically important effects of climate change include disruption of the phenology of species, shifts in timing of species life cycle and consequent mismatch in the occurrence of interacting species which has been reported for insects and their interacting partners as well as other species (Burkle et al., 2013: Delucia et al., 2012: Lavergne et al., 2010: Willis et al., 2008). The response of indiridual species to climate change is linked to the climatic origin and evolutionary history of the species (Anderson et al. 2012). This implies that tropical and temperate species may vary in their response to ecological challenges presented by climate warming. Furthermore, indiridual species are likely to respond independently to climate change effects (Hannah et al., 2005). Consequently, species specitic range shift modelling will play a critical role in providing climate change-integrated conservation strategies especially for highly mobile taxa such as insects (Hannah et al., 2002). While the political debate about climate change focus mainly on global temperature rise, the synergy of climate change with other anthropogenic factors such as habitat fragmentation has greater consecuences for biodiversity especially for organisms such as insects (Hannahe al. 2005: Peter and I orejoy. 1492). This is particularly important in the tropics with records of high rates of habitat loss. frasmentation and deforestation which conded amplify the synergistic effects of climate change on insects and other organisms (Hamnah el al.. 20(5). Most findings till date have reported range shift in distribution and abundance of insects towards the poles and higher elevations especially for insect rectors and pests (Camnonet al. 1998: Diffenbaugh ef cl.. 2008: Parmesan and Yohe, 2003). Few of the studies on beneticial insects such as bees have been done mostly in the temperate and Mediterrancan regions. Recent reports on 67 species of European and North American bumblebees show range loses from the southern range limits of the bees and lack of corresponding shift to the cooler climate above their northern range limit (Kerr et al., 2015). These important findings provide opportunity to proffer solutions to mitigate future losses such as experimental relocation of colonies as suggested for bumble bees (Kerr et al., 2015). Crucial ecological data such as this is important to plan for conservation of tropical insect species which are also prone to the threats of climate change (Moir e' al.. 2014). This will contribute positively to conservation and promote ecosystem service such as pollination in the tropies. Pollination in this region depends more on arailability of wild pollinators since the farmers are mostly peasants who cannot afford the huge funds required for commercial pollinators such as honeybees as often used on a large scale by farmers in the temperate region.

\section{Sampling Difficulties and Habitat Loss}

Phylogenetic studies have indicated that the tropics is characterized by high speciation rate compared to the temperate region of the earth (Condamine et al., 2012; McKenna and Farrell, 2006). The monotonic increase in insect diversity towards the tropics has been attributed to complex results of evolutionary history and ecological interactions (Mittelbach et al.. 2007; Schemske, 2009). However, despite the extraordinary diversity of insects in the tropics. there are limitations in the taxonomic and ecological studies of this group leading to the arailability of little information about the insects present in the tropies (Godfray et al., 1999: Norotny et al., 2002). Thick canopy corer and dense vegetation are characteristics of natural habitats in the tropics. Researchers have been faced with challenges about insect sampling mest especially in the natural habitats in this region. This has discouraged intensive sampling ol insects. Although, current estimate indicates a very high proportion of insects. howerer. members of this taxon are less studied compared (1) vertebrates and other groups in the tropies (Samways, 2005). 
Over the years, habitat degradation and other human activities have led to the loss of important species of flora and fauna in the tropics. Although high species composition has been observed. however. the rate of habitat degradation and destruction is higher in the tropics compared to any other biome (Pimm. 2001; Sala et al., 2000). Approximately half of the earth's closed-canopy tropical forest has already been converted to other uses (Wright. 2005). The conversion of natural areas into agricultural areas as well as for the purpose of urbanization has greatly influenced the loss of significant number of species of insects from their habitats (Tscharntke et al., 2005). A good number of species of insects are extinct and a higher population is endangered as a result of over-exploitation of the environment through human activities. According to May et al., (1995), if the progression of human activities is kept constant, especially in tropical ecosystems, several species of insects will be lost before they are identified.

\section{Alien Invasion}

Biological invasion is one of the key drivers of biodiversity loss globally, often acting in synergy with other important threats such as habitat loss and climate change (Brook et al., 2008). While native insects in their home ranges are susceptible to threats from invasive plants and animals, invasive insects also pose threat to other species and important ecological interactions in invaded environments (Gaigher et al., 2011). Stable climatic and ecological conditions in tropical ecosystems makes this region prone to the disruptive activities of invasive insects. Mutualism between invasive ant Pheidole megacephala and honeydewproducing hemiptera Dysmicoccus sp. and Pulvinaria arbicola on Cousine Island. a tropical Island in the Seychelles has been identified as one of such disruptive activities causing serious threat to the ecosystem of the island (Gaigher et al.. 2011). This trophobiotic mutualism enhances the population of the ants and the hemipterans known to be responsible for the defoliation and destruction of Pisonia grandis trees which are of immense structural and functional importance in the Seychelles. The trees serve as nesting and roosting site to seabirds and as raluable source of organic matter on the island. Furthermore, there have been records of tropical insect species becoming invasive and well adapted to other climatic regions. and extending beyond their native ranges in the tropies. Tropical fire ants, -Solenopsis sp. have become invasive in USA, Australia, China and Taiwan posing serious agricultural and health threats in the tropical, temperate and Mediterranean ecosystems in these countries. It is important to promote research that focuses on careful management of invaded tropical ecosystems to guarantee restoration through eco-friendly approaches (Gaigher etal., 2013).

\section{Taxonomic Challenges}

Successful biodiversity conservation research and implementation is founded on a synthesis of other biological science disciplines such as ecology, taxonomy; genetics, biogeography, evolution among others (Khuroo et al., 2007). Engaging practitioners in these conservationrelated disciplines is needed to estimate how much genetic, species, community, biotope and ecosystem diversity are available and at what rate they are being lost and to give possible directives on how to a rest declines (Samways, 1993).

Taxonomy wish involves discovery, description and identification of new species has suffered a lot setbacks ranging from perception to porit funding as well as dearth of trained taxonomists and para-taxonomists who specialize in description of various taxa out of the vast array currently known to science (Godfray. 2002). This is especially true for insects for which there are speculations that probably only $7-10 \%$ of species have been described (Samways, 1993). These limitations are more pronounced in the tropics due to the enormous diversity attributed to this region with estimates of $1-5 \%$ odescribed species of insects. Despite the urgency of calls and awareness for insect conservation in the tropics (Brown, 1997), financial and technical resources setbacks have limited attempts to overcome taxonomic challenges plaguing conservation in the tropics 
(Samways. 1993). Most of the insects that have been catalogued to date are temperate region species with far more species in the tropics yet to beknown (Hoffman and Vaughan, 2003).

\section{What Can BeConserved: Triage and Approach?}

Evidence has been provided in support of various perspectives for prioritizing insect conservation planning (Liow et al., 2001). Researchers and conservation planners have engaged approaches ranging from habitatfocused to organism-focused insect conservation (Samways, 2007). Towards successful insect conservation, there is a growing need to outline carefully selected priorities and well established conservation approaches to ensure adequate optimization of the finite resources and finances available for conservation. From the habitat perspective, global scale analysis has identified about 25 hotspots of biodiversity (Myers et al., 2000) which are found mostly in the tropics, from the Tropical Andes on the West to the Philippines on the East (Bradshaw et al., 2009). However, there is need for caution when using hotspots in selecting areas of high priority for conservation (Bradshaw et al., 2009). Biodiversity hotspot selection approaches which utilize a single index may not sufficiently provide surrogate for other aspects of biodiversity that are paramount to conservation planning. This has been shown for bird conservation planning with lack of congruence found in selection of priority areas for bird diversity conservation when indices ranging fiom species richness to endemism and threatened species were used in biodiversity hotspot selection (Orme et al., 2005). There is a need for similar inrestigations for insects. From the habitat perspective, approaches have also varied fromemphasis on preservation of prestine tropical regetation that keeps intact both terrestrial and aquatic resourees that support dirersity of insects (Schowalter, 2009). Howerer. attention has been drawn to conservation approaches that embrace sustainable use of resources in the form of wildlife-friendly agriculture and agroforestry that support biodiversity while at the same time utilizing environmental resources to cater for various human needs (Samways. 2005). Methods such as organic farming, integrated or mixed farming have been shown to promote diversity of insects and their associated ecological interaction in tropical ecosystems (Klein et al., 2003). Establishment of ecological networks has also been used as an eco-friendly measure that support diversity of insects as well as diversity of other flora and fauna species in tropical agroforestry systems (Pryke and Samways, 2015).

Endangered and threatened species are also of paramount consideration in setting priorities for insect conservation (Maes et al., 2004). Current estimations have shown that over 11,000 species of insects have gone extinct since 1600 with majority of these being tropical insects. There are as well projections that more burgeoning extinction rates may be in view in the nearest future if current trends of loss are not curtailed in tropical forests (Hoffman and Vaughan, 2003; Samways, 1994). This implies endangered and threatened species have to be identified and targeted conservation strategies outlined to rescue these species. This may involve efforts such as conservation ranching that could protect and conserve critical habitats where appropriate tropical forests with desirable resources for the targeted insect groups are left intact (Hoftman and Vaughan, 2003).

A functional approach to biodiversity conservation begins with linking critical ecosystem services to the service providing organisms in both natural and production landscapes. It also involves identifying and estimating the level of threat being faced by the service providers at local. landscape and regional scales (Brittain e't cl., 2010). For insects, the critical ecosystem services they provide include pollination which they deliver to crops and native plant species (Klein et al., 2007: Tepedino, 1979). Others include pest control which is ol high priority in the tropics as well as nutrient cycling. It is important to estimate the community composition of rarious insect functional groups in natural, agricultural and agroforestry landscapes. Such assessments should be carried out on adequate temporal and 
spatial scales to account for variations in community composition as a result of temporal and spatial beta diversity (Kehinde and Samways, 2014). This is important since tropical rainforests are known to have high spatial heterogeneity which generates high beta diversity (Lewis and Basset, 2007; Vasconcelos et al., 2000). This will provide baseline information to ensure conservation effort that will guarantee sufficient species pool of insects required to provide crucial ecosystem services. This ensures functional complementarity with functions from several species within the same functional group contributing to high overall functional performance level (Tscharntke et al., 2005 ) including reducing functional redundancy. Resilience which is the ability to reorganize after disturbances is also guaranteed when the community composition of species providing a particular ecosystem function are conserved.

\section{CONCLUSION}

Insect conservation in the tropics requires holistic approach which ranges from filling crucial knowledge and data gaps in terms of sampling, taxonomy and inventory of tropical insects as well as eco-friendly management practices that support insect diversity in production and natural landscapes. Conservation planning and action should integrate both temporal and spatial scale approaches considering the fact that most of the threats driving tropical insect diversity loss act synergistically at these two scales. These will ensure enhanced prospects for insect diversity conservation as well as promotion of the important ecosystem services offered by insects in tropical landscapes.

\section{ACKNOWLEDGENIENTS}

Thanks to Prof. Micheal Samways for his comments on an earlier draft of the manuscript.

\section{REFERENCES}

Anderson, J. T., Panetta, A. M. and MitchellOlds, T. (2012). Evolutionary and ecological responses to anthropogenic climate change. Plant Phisiologl; 4:1728-1740.

Basset, Y. (1999). Diversity and abundance of insect herbivores foraging on seedlings in a rainforest in Guyana. Ecological Entomologr 24: 245259.

Bradshaw, C.J.A., Sohdi, N.S. and Brook, B.W. (2009). Tropical turmoil: abiodiversity tragedy in progress. Frontiers in Ecologr and the Environment 7: 79-87.

Brittain, C.A., Vighi, M., Bommarco, R., Settele, J. and Potts, S.G. (2010). Impacts of a pesticide on pollinator species richness at different spatial scales. Basic and Applied Ecology; 11: 106-115.

Brook, B.W., Sohdi, N.S. and Bradshaw, C.J.A. (2008). Synergies among extinction drivers under global change. Trends in Ecolog and Evolution, 23:453-460.

Brown, K.S. (1997). Diversity, disturbance and sustainable use of neotropical forest: Insects as indicator for conservation monitoring. Journal of Insect Conservation, 1:25-42.

Burkle, L.A., Marlin, J. C. and Knight, T.M. (2013). Plant-pollinator interactions over 120 years: loss of species, co-occurrence and function. Science 339: 1611-1615.

Cannon, C. H., Peart, D. R. and Leighton, M. (1998). Tree species diversity in commercially logged Bornean rainforest. Science, 281: $1366-1368$.

Clark, J.A. and May, R.M. (2002). Taxonomic bias in conservation research. Science, 297: 191-192.

Condamine, F.L., Sperling, F.A.H., Wahlberg, N., Rasplus, J-Y. and Kergoat, G. J. (2012). What causes latitudinal gradients in species diversity? Evolutionary processes and ecological constraints on swallowtail biodiversity. Ecologr Letters, 15:264-277.

DEFRA (2002). Action plan to develop organic food and farming in England. Retrieved from:

(http: www.defra.gov.uk/farm/organic/act ionplan index.htm).

Delucia, E.H., Nabity, P.D., Zavala, J.A. and Berenbaum, M.R. (2012).Climate change: Resetting plant-insect interactions. Plant Phisiolog: 160: 1677-1685.

Diffenbaugh, N.S., Krupke, C. H., White, M.A. and Alexander, C. E. (2008). Global warming presents new challenges for maize pest management. Environmental Research Letter, 3:1-9.

Dirzo, R. and Raven, P.H. (2003).Global state 
of biodiversity and loss. Anmual Revien of Environment and Resources, 28: 137-167.

Erwin, T. L. (1982). Tropical forests: their richness in Coleoptera and other arthropod species. The Coleopterist's Bulletin, 36: 74-75.

Gaigher, R., Samways, M.J., Noort, S.V.(2013). Saving a tropical ecosystem from a destructive ant-scale (Pheidole megacephala, Pulvinaria urbicola) mutualism with support from a diverse natural enemy assemblage. Biological Invasions, 15:2115-2125.

Gaigher, R., Samways, M.J., Henwood, J. and Jolliffe, K. (2011). Impact of a mutualism between an invasive ant and honeydew-producing insects on a functionally important tree on a tropical island. Biological Invasions 13: 1717-1721.

Godfray, H.C.J. (2002). Challenges for taxonomy. Nature, 417: 17-19.

Godfray, H.C.J., Lewis, O.T. and Memmott, J. (1999). Studying insect diversity in the tropics. Philosophical Transactions of the Royal Society of London B 354: 1811-1824.

Greenfacts (2012). Scientific facts on biodiversity and human well being. Retrieved from:

http:/www.greenfacts.org/en/biodiversity

Hannah, L., Lovejoy, T.E. and Schneider, S.H. (2005). Biodiversity and climate change in context. In: Climate Change and Biodiversity (Lovejoy, T.E. and Hannah, L. eds), pp 3-14. Yale University Press, London, United Kingdom.

Hannah, L., Midgley, G.F., Lovejoy, T.E, Bond, W.J., Bush, M., Lovett, J.C., Scott, D. and Woodward, F.I. (2002). Conservation of biodiversity in a changing climate. Conservation Biologl: 16:264-268.

Hoffman, B.S. and Vaughan, D.M. (2003). Endangered insects. In: The Encyclopedia of Insects(Resh. V. H. and (arde, R.eds.), pp 1-7. Academic Press. San Diego. CA.

Kehinde, T.O. and Samways, M.J. (2014). Management defines species turnover of bees and flowering plants in vineyards. Agricultural and Forest Entomologr: 15: (95-10)1.

Kehinde, T. O., Amusan B., Aransola, A., Oyelade, S., and Adu, W. (2014). Status of insect diversity conservation in Nigeria: A review. Ife Jounal of Science, 16: 319330 .
Kerr, J. T., Pindar, A., Galpern, P., Packer, L., Potts, S. G., Roberts, S. M., Rasmont,P., Schweiger, O., Colla, S. R., Richardson, L. L.. Wagner, D.L.andGall,L.F.(2015). Climate change impacts on hamblebees converge across continents: Science. 349: 177-180.

Khuroo, A.A., Dar, D.H., Khan, Z.S. and Akhtar, H.M. (2007). Exploring an inherent interface between taxonomy and biodiversity: current problems and future challenges. Joumal of Nature Conservation, 15: 256-261.

Klein, A.M., Steffan-Dewenter, I. and Tscharntke, T. (2003). Pollinator diversity and fruit set of Coffeacanephora in relation to local and regional agroforestry management. Journal of Applied Ecology 40: 837-845.

Klein, A. M., Vaissiere, B. E., Cane, J.H., Steffan-Dewenter, I., Cunningham, S.A., Kremen, C. and Tscharntke, T. (2007). Importance of pollinators in changing landscapes for world crops. Proceedings of the Royal Society; B274:303-313.

Laurance, W.F. (1999). Reflections on the tropical deforestation crisis. Biological Conservation, 91: 109-117.

Lavergne, S., Mouquet, N., Thuiller, W. and Ronce, O. (2010). Biodiversity and climate change: Integrating evolutionary and ecological responses of species and communities. Annual Reviciv of Ecology: Evolution, and Systematics 41:321-350.

Lewis, O.T. and Baset, Y. (2007). Insect conservation in tropical forests. In: Insect Conservation Biology (Stewart, A.J.A., New, T.R. and Lewis, O.T. eds.) pp. 34-56. The Royal Entomological Society, London, U.K.

Liow, L.H., Sodhi, N.S. and Elmqvist, T. (2001). Bee diversity along a disturbance gradient in tropical lowland forests of Southeast Asia. Journal of Applied Ecologr:38: 180-192.

Maes, D., Vanreusel, W., Talloen, W. and Van Dyck H. (2004). Functional conservation units for the endangered Alcon Blue butterfly Maculinea alcon in Belgium (Lepidoptera: Lycaenidae). Biological Conservation, 120:229-241.

May, R.M., Lawton, J.H. and Stork, N.E. (1995). Assessing extinction rates. In: Extinction Rates (Lawton. J.H. and May, 
R.M. eds.).pp 1-24. Oxford University Press. Oxford. U.K.

McKenna, D.D. and Farrell, B.D. (2006). Tropical forests are both evolutionary cradles and museums of leaf beetle diversity: Procesdings of the National Academ of Science USA. 103: 10947-10951.

Mittelbach, G.G., Schemske, D.W., Cornell, H.V., Allen, A.P., Brown, J. M., Bush, M.B., Harrison, S. P., Hurlbert, A. H., Knowlton, N. and Lessios, H. A. (2007). Evolution and the latitudinal diversity gradient: speciation. extinction and biogeography. Ecology Letters. 10:315.331.

Moir, M., Hughes, L., V'esk, P.A. and Leng, M.C. (2014). Which host-dependent insects are most prone to coextinction under changed climates? Ecology and Evolution 4: 1295-1312.

Mora, C., Tittensor, D.P., Adl, S., Simpson, A.G.B. and Worm, B. 2011. How many species are there on Earth and in the ocean? PLoS Biology 9: e 1001127.

Musolin, D. L. (2007). Insects in a warmer world: Ecological, physiological and lifehistory responses of true bugs (Heteroptera) to climate change. Global Change Biology; 13: 1565-1585.

Myers, N., Mittermeier, R.A., Mittermeier, C.G., Da Fonseca, G.A.B. and Kent, J. (2000). Biodiversity hotspots for conservation priorities. Nature, 403:853-858.

Novotny, V.. Basset, Y., Miller, S.E., Weiblen, G.D., Bremer, B., Cizek, L. and Drozd, P. (2002). Low host specificity of herbivorous insectsina tropical forest. Nature, 416:841 $8+4$.

Novotny, V., Drozed, P., Miller, S.E., Kulfa, M., Janda, M., Basset, Y. and Weiblen, G. (2006). Why are there so many species of herbivorous insects in tropical rainforests? Science. 313:1115-1118.

Orme, C.D.L., Davies, R.G., Burgess, M., Eigenbrod, F., Pickup, N., Valerie, A.O., Webster, A.J.. Ding, T-S., Rasmussen, P.C., Ridgely, R.S., Stattersfield, A.J., Bennett. P.M., Blackburn, T.M., Gaston, K.J. and Owens, I.P.F. (2005). Global hotspots of species richness are not congruent with endemism or threat. Nature 436:1016-1019.

Parmesan, C. and Yohe, G. (2003). A globally coherent fingerprint of climate change impacts across natural systems. Nature, 421 : $37-42$.

Peter, R.L. and Lovejoy, T.E. (1992). Global Warming and Biological Diversity. London: Yale University Press. $4(0) \mathrm{pp}$

Pimm, S. L. 2001. The world according to Pimm: a scientist audits the earth. McGrawHill. New York. 3()4 pp.

Pimm, S.L., Jenkins, C.N., Abell, R., Brooks, T.M., Gittleman, J.L., Joppa, L., Raven, P.H., Roberts, C.M. and Sexton, J.O. (2014). The biodiversity of species and their rates of extinction. distribution. and protection. Science, 344: 1246752-1246760.

Pryke, J. S. and Samways, M. J. (2015). Conserving natural heterogeneity is crucial for designing effective ecological networks. Landscape Ecologi; 30: 595-607.

Rands, M.R.W., Adams, W.A., Bennun, L., Butchart, S.H.M., Clements, A., Coomes, D., Entwistle, A., Hodge, I., Kapos, V., Scharlemann, J.P.W. Sutherland, W.J.andVira, B. (2010). Biodiversity Conservation: Challenges beyond 2010 . Science, 329: 1298-1303.

Sala, O.E., Chapin, F.S., Armesto, J.J., Berlow, E., Bloomfield, J., Dirzo, R, Huber-Sanwald, E., Huenneke, L.F., Jackson, R.B., Kinzig, A., Leemans, R., Lodge, D.M., Mooney, H.A., Oesterheld, M., Poff, N.L., Sykes, T.M., Walker, H.B., Walker, M. and Wall, D.H. (2000). Global biodiversity scenarios for the year 2100 . Science, 287: 1770-1774.

Samnegărd, U., Hambäck, P.A., Eardley, C., Nemomissa, S. and Hylander, K. (2015). Turnover in bee species composition and functional trait distributions between seasons in a tropical agricultural landscape. Agriculture, Ecosistems and Environments $211: 185-194$

Samways, M.J. (1993). Insects in biodiversity conservation: some perspectives and directives. Biodiversity (onservation. 2: $258 \quad 282$.

Samwars, MI.J. (1994). Insect Conservation Biologl: (hapman and Hall. Iondon. U.K. $358 \mathrm{pp}$.

Samways, M.J. (2005). Inseet Diversity Conservation. Cambridge University Press. London, U.K.356pp.

Samways, M.J.(2007). Connecting biodiversity: 
Trends in Ecology and Evolution, 22: 60).

Schemske, D.W. (2009). Biotic interactions and speciation in the tropies. In: Speciation and Patterns of Diversity. (Bultin. R.. Bridle, J. and Schluter. D. eds). pp. 219239 , Cambridge University Press. Cambridge. United Kingdom.

Schowalter, T. (2009). Insect Ecology: An Ecosystem Approach. Academic Press Cambridge, Massachusetts United States. $774 \mathrm{pp}$.

Shah, A. (2011). Addressing Biodiversity Loss. Retrieved from: http://ww:globalissues.org/article/787/ad dressing-biodiversity-loss.

Tepedino, V. J. (1979). The importance of bees and other insect pollinators in maintaining floral species composition. Great Basin Naturalist Memoirs, 3: 139-150.

Thomas, C.D., Cameron, A., Green, R.E., Bakkenes, M., Beaumon, L.J., Collingham, Y.C., Erasmus, B.F.N., Ferreira de Siqueira, M., Grainger, A., Hannah, L., Hughes, L., Huntley, B., van Jaarsveld, A.S., Midgley, G.F., Miles, L., Ortega-Huerta, M.A., Peterson, A.T., Phillips, O.L. and Tscharntke, T., Klein, A-M., Kruess, A., Steffan-Dewenter, I. and Thies, C. (2005). Landscape perspectives on agricultural intensification and biodiversity: ecosystem service management. Ecology Letters, 8: 857-874.

Tscharntke, T., Bommarco, R., Clough, Y., Crist, T.O., Kleijn, D., Rand, T.A., Tylianakis, J.M., van Nouhuys, S. and Vidal, S. (2008). Conservation biological control and enemy diversity on a landscape. Biological Control. 45:238-253.

Tylianakis, J.M., Laliberté, E., Nielsen, $\Lambda$. and Bascompte, J. (2010).Conservation of species interaction networks. Biolegical Conserutum, 143:227()-2279.

Vasconcelos, H.L., Vilhena, J.M.S. and
Caliri, G.J.A. (2000). Responses of ants to selective logging of a central Amazonian forest. Jounnal of Applied Ecology: 37: $508 \quad 514$.

Willis, C.G., Ruhfel, B., Primack, R.B., Miller Rushing, A.J. and Davis, C.C. (2008). Phylogenetic patterns of species loss in Thoreau's woods are driven by climate change. Proceedings, National Academy of Sciences, USA, 105: 1702917033.

Wright, S.J. (2005).Tropical forests in a changing environment. Tiends in Ecologl: and Evolution, 20:553-560.

Tscharntke, T., Klein, A-M., Kruess, A., Steffan-Dewenter, I. and Thies, C. (2005). Landscape perspectives on agricultural intensification and biodiversity: ecosystem service management. Ecologr Letters, 8: 857-874.

Tscharntke, T., Bommarco, R., Clough, Y., Crist, T.O., Kleijn, D., Rand, T.A., Tylianakis, J.M., van Nouhuys, S. and Vidal, S. (2008). Conservation biological control and enemy diversity on a landscape. Biological Control, 45:238-253.

Tylianakis, J.M., Laliberté, E., Nielsen, A. and Bascompte, J. (2010). Conservation of species interaction networks. Biological Conservation, 143:2270-2279.

Vasconcelos, H.L., Vilhena, J.M.S. and Caliri, G.J.A. (2000). Responses of ants to selective logging of a central Amazonian forest. Jounal of Applied Ecology 37: 508-514.

Willis, C.G., Ruhfel, B., Primack, R.B., Miller Rushing, A.J. and Davis, C.C. (2008). Phylogenetic patterns of species loss in Thoreau's woods are driven by climate change. Procecedings, National Academy of Sitences. LSA. 105:17029-17033.

Wright, S.J. (2005). Tropical forests in a changing environment. Trends in Ecolog:

Kehinde. T.().

Vigerian terumel of linemoleger

Published by the Entumulogical Soctety of Nigeria

"Iw⿻.esn.urung

ISSN: $0331-(0) 44$

Volume 3.3. 2017

pp 7-15

DOI: $10.36108 / \mathrm{NJE} / 7102 / 33(0120)$

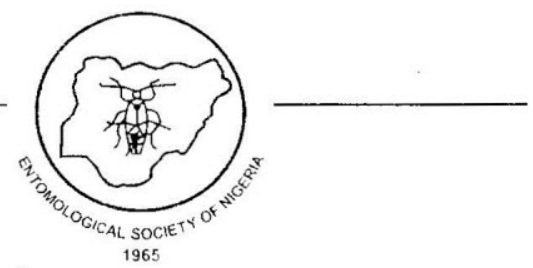

